\title{
Tegnspråktolking, profesjon i diskursiv klem
}

Ingeborg Skaten

Høgskolen i Bergen

Ingeborg.Skaten@hib.no

\author{
Keywords \\ sign language \\ Interpreters \\ profession \\ discourse \\ social change
}




\section{Abstract}

\section{The profession of Sign Language interpreter, caught between discourses}

This article discusses the profession of Sign Language interpreter in Norway today, and in doing so identifies the discourses that are competing to define the profession.

From a sociological perspective, any profession - a term that is taken here as meaning an occupational group that meets some specific criterion - is a social construction. No such criterion is absolute, but must be understood in a temporal and geographical context. A trait common to all the professions in our welfare state is that they are founded on the basis of trust from the society that they exist to serve.

This is why it is important for any profession to demarcate itself from other professions, thereby clarifying - both for its own members and, even more so, for the public - what its clients are entitled to expect. What kind of expertise does the profession possess? And regarding professional conduct, what are its members permitted - and not permitted - to do?

A key consideration is professional ethics or standards. These are communicated to the public so that members of the public will be aware what they can ask for, and what they are entitled to receive, when booking the services of, for example, an interpreter.

In Norway it is Tolkeforbundet, the Association of Sign Language interpreters, which establishes guidelines for the interpreters' professional conduct. However, both the profession's ethics and the profession as such are subject to constant change.

The aim of my analyses is to investigate the nature of the discourses that are currently engaged in this process. First we need to identify the social actors that are in a position to influence the construction of the profession that is Sign Language Interpreter. Given the way that this special interpreter service is organised, Nav (the Norwegian Labour and Welfare Administration) is in a powerful position, along with educational institutions and the profession itself.

The Norwegian Association of the Deaf (NDF) is also an institution of particular interest here. There would be no Sign Language interpreters, let alone professional Sign Language interpreters, without the political struggle initiated by this association. Today Sign Language is recognised as one of Norway's official languages. This is a result of the language discourse that has materialized in governmental papers.

However, it is not the acceptance of Deaf culture and language that entitles deaf people to use the services of interpreters, but rather the notion of deaf people as 'handicapped'. Hence these competing discourses of language and handicap, which form part of the social construction of deafness, may also be identified as defining the interpreter. The former discourse (language) emphasizes the languages in use, while the latter (handicap) defines the interpreter as an aspect of the rehabilitation of people whose hearing is impaired.

Here I focus on a text recently issued by Nav, in so far as it relates to the interpreter's role. I analyse the text to identify how this role is articulated within the Nav discourse, particularly in relation to the way the profession defines this role in its code of ethics.

I will argue that some of the changes in the interpreter's role that are suggested in the Nav report are quite radical. Given the institutional power of Nav, this leaves the profession in a dilemma. In which direction will it move, and what will the consequences be? 


\section{Innledning}

På noen områder skiller tegnspråktolking seg fra taletolking, som tolkens arbeidsspråk: norsk og norsk tegnspråk, yrkets historikk og ikke minst i måten tolketjenesten er organisert på her i landet. Når det kommer til selve tolkeprosessen, er det mer som forener enn som skiller - felles for all tolking er at det handler om oversetting, en krevende, språklig praksis.

Det er imidlertid ikke tolking som spesialisert sosial praksis som har fokus her, men tolkens profesjon, som sosial konstruksjon. En hver profesjon oppstår i tid og rom - og legitimeres ut fra velferdsstatens behov. I Norge er det Nav som distribuerer velferdsgodet «tolk for døve, døvblitte og hørselshemmede», tolkebrukere med individuelle rettigheter til tolk, forankret i folketrygdloven.

Begrepet tolk har to dimensjoner i tekster om tegnspråktolken: som velferdsgode og som profesjon. Retten til tolk som velferdsgode er det døveorganisasjonen som har kjempet fram. Og døves kollektive identitetsarbeid har hatt, og har fortsatt, innvirkning på hvordan vi forstår profesjonen (Skaten, 2005). La oss først se på profesjonsbegrepet, som her legges til grunn.

«To say a profession exists, is to make it one» (Abbott, 1988, s. 81). Spissformuleringen uttrykker at profesjoner er sosiale konstruksjoner, men hva med innholdet? Det kreves en form for ekspertise for å utøve profesjonen, og det er dette som ligger i Abbotts beskrivelse når han sier at en profesjon er en «occupational group with some spesial skill» $(1988, \mathrm{~s} .7)$. Men hvordan oppnås slik ekspertise?

De fleste profesjonsforskere vil vise til sammenhengen mellom utdanning og yrke, som et kriterium for i hvilken grad et yrke kan kalles en profesjon. Torgersen (1972) peker på at jo lengre utdanning og jo tettere kobling mellom yrke og utdanning, jo større profesjonsgrad. En slik tett koblingen er tydelig hos tegnspråktolkene, som $\mathrm{i}$ dag må ha en tre-årig bachelorutdanning for å bli godkjent som tolk «for døve, døvblinde og hørselshemmede». Bestått eksamen fungerer som sertifisering av tolken.

Utdanning på høyere nivå er også ett av flere kriterier hos Wilensky (1964). Etisk kode, fulltidsstillinger og opprettelse av interesseorganisasjon, er andre kriterier eller stadier han lister opp. Tegnspråktolking har gått gjennom alle disse stadiene i utviklingen fra yrke til profesjon (Skaten, 2005).

Tegnspråktolkenes organisasjon, Tolkeforbundet, representerer profesjonen, men er ikke alene om à ville definere denne. Profesjonens juridiksjon, retten til à definere sine oppgaver, vil alltid utfordres av andre aktører. Nav er en av disse (Skaten, 2013). Foruten a distribuere velferdsgodet tolk, er Nav også arbeidsgiver for tolkene ${ }^{1}$ og tekster fra denne aktøren får derfor spesiell interesse for min problemstilling:

\section{Hvilke diskurser påvirker tolkens profesjon og i hvilken retning?}

Diskurser er bestemte måter å forstå og snakke om verden på, som trekker sosiale og lingvistiske grenser for hva det er mulig å tenke, si eller gjøre (Syltevik, 2013, s.32). Innenfor ett sosialt domene kan flere diskurser kjempe om hegemoniet, som i sosial konstruksjon av døvhet: som funksjonshemmede eller som språklig minoritet (Breivik, 2000). En kamp som har betydning også for hvordan vi forstår tolken.

1 Som det framgår av Tolkeutredningen (2008) har praktisk talt alle tolker det her er snakk om, et arbeidsforhold til Nav - enten som ansatte eller gjennom andre avtaler som regulerer deres lønn. Tolketjenesten er lagt til hjelpemiddelsentralene, som ligger under Nav. 
Haualand (2002) har studert hvordan døveorganisasjonen spiller på ulike diskurser som er til rådighet for å oppnå sine mål, og konkluderer med at døve ikke kan forstås som enten funksjonshemmede eller som språklig minoritet, men som begge deler.

Skaten (2005) finner at parallelt med døves artikulering av sin identitet som språklig gruppe, har tolkens tittel gjennomgått det Fairclough (1992) kaller en rewording, fra « øvetolk» til «tegnspråktolk».

Språkdiskursen har også skrevet seg inn i strukturer som regulerer språkopplæring av døve barn og i stortingsmeldingen Mål og meining, 2008, der norsk tegnspråk făr status som ett av Norges offisielle språk. Men så langt har ikke statusen som offisielt språk utløst noen rettigheter til tolk. Rettighetene er fortsatt forankret i diskursen om døve som funksjonshemmede, og i det perspektivet er tolken, eller «tolkehjelp», del av et «rehabiliteringstilbud» til hørselshemmede (Et helhetlig rehabiliteringstilbud til hørselshemmede, 2002).

Når døveorganisasjonen hevder at det er «gjennom erkjennelse av vårt språk og kultur» at døve har oppnådd rettigheter til tolk (Gjøen, 2012), må det derfor ses som en politisk ytring. Denne språkdiskursen finner vi igjen i Tolkeforbundets etiske retningslinjer (Tolkeforbundet, 2011) der tolken artikuleres som ren språktolk.

Ser vi til Sverige, har døves språkdiskurs også manifestert seg i offentlig tekst om tolketjenesten: «Synsättet på tolktjänst förandras från ett vårdperspektiv till ett språk- og tilgänglighetsperspektiv» (En samlad tolktjänst, s. 20). Men heller ikke her utløser den noen rett til tolk og tolken befinner seg i spenningen mellom to rivaliserende diskurser - som et hjelpemiddel for funksjonshemmede og som ren språktolk.

Nav har nå varslet fornying av tolketjenesten i en rapport som tar for seg både organisering av tjenesten og oppgaver for tolken (Fornying av tolketjenesten, 2011). I denne artikkelen skal jeg sette søkelyset på hvilke diskurser som der forsøker å definere tolken.

\section{Teori og metodisk tilnærming}

Jeg følger i denne artikkelen noen sosial-konstruksjonistiske antakelser der jeg bygger på Burr (2003, s. 2-5) som definerer fire premisser for en slik forståelse:

1) en kritisk innstilling overfor viten som tas for gitt

2) historisk og kulturell spesifisitet

3) sammenheng mellom kunnskap og sosiale prosesser

4) sammenheng mellom kunnskap og sosial handling

Punkt to er sammenfallende med hvordan både «tolk» og «profesjon» forstås, i denne artikkelen; som noe som skapes i tid og rom. De øvrige punktene danner utgangspunkt for min analyse, som særlig er inspirert av Faircloughs kritiske diskursanalyse (KDA), men også Laclau og Mouffes diskursteori, begge presentert i Jørgensen og Phillips (1999). Begge disse teoretikerne har utgangspunkt i strukturalistisk og post-strukturalistisk språkfilosofi, som hevder at vår tilgang til virkeligheten alltid går gjennom språket.

Faircloughs (1992) tredimensjonale modell for kritisk diskursanalyse (KDA) er en metodisk tilnærming som ikke er politisk nøytral, men har et kritisk perspektiv som er opptatt av sosial forandring. KDA har som formål å kartlegge forbindelsen mellom språkbruk og sosial praksis. Fokus er på de diskursive praksisers rolle $\mathrm{i}$ opprettholdelsen av den sosiale orden og i sosial forandring. 
Innledningsvis har jeg forklart diskurs som måter en kan snakke om og forstå verden på. I Discourse and Social Change forklarer Fairclough (1992) diskurser som a domain in which social struggles take place, and change in discourse as a dimension of wider social and cultural change (side 28).

Det er ikke én måte å utføre en kritisk diskursanalyse på, understreker Fairclouch, men han anbefaler en analytisk ramme for analyse av en kommunikativ handling og dens tre dimensjoner:

- tekst (tale, skrift, bilder eller en blanding av det språklige og det visuelle)

- diskursiv praksis: produksjon og konsumpsjon av tekster

- sosial praksis

Eksempler på kommunikativ handling kan være en avisartikkel, en film eller et intervju. I denne artikkelen er det Nav-dokumenter som analyseres, med en lingvistisk tilnærming til teksten, på ordvalgnivå. Hvilke sosiale aktører som har produsert teksten og for hvem, distribusjon av teksten og sosial praksis inngår også i analysen. Ved å identifisere diskurser som opptrer i teksten, kan betydning for videre sosial praksis også diskuteres.

Forskerrollen er ikke nøytral og det er viktig for meg å si noe om mitt ståsted i forhold til feltet jeg undersøker. Som ansatt innen tolkeutdanningen (som i analysen behandles som én institusjon), medlem av tolkeprofesjonen og dessuten med sterk tilknytning til brukerorganisasjonen Norges Døveforbund (NDF), er jeg selv både påvirket av og påvirker de diskurser jeg her skal undersøke. Dermed påhviler det meg et ansvar for å gi leseren mulighet til selv å ta stilling til mine slutninger og derfor gjengis punkt 4.5 i Nav-rapporten det her refereres til, i sin helhet. Se figur 1, side 13-14: «Tiltak for à utvikle tolkens rolle $\mathrm{i}$ hjelpemiddelsentralene» (Fornying av tolketjenesten, 2011, s. 17-18).

Som kritisk diskursanalytiker tar jeg stilling, og min agenda er å rette søkelyset mot diskursive praksiser som kan føre til endring for forståelsen av tolkerollen, og dermed også for profesjonen.

\section{Analyse og diskusjon}

Tolkeforbundets yrkesetiske retningslinjer uttrykker profesjonens syn på tolken, dens rolle eller funksjon. Denne profesjonsetikken utgjør et bakteppe for min diskusjon om tolkens rolle slik den framstilles i Nav-dokumenter og da særlig i rapporten om fornying av tolketjenesten (Fornying av tolketjenesten, 2011).

Innledningsvis har jeg vist at antagonistiske diskurser kjemper om hegemoniet både $\mathrm{i}$ forståelsen av «døve» og «tolk» som sosiale konstruksjoner. Det er tegn som tyder på at dette er områder som er åpne for endring, og vi ser at en språkdiskurs hevder seg i konkurranse til den rådende funksjonshemmet-diskursen. For min analyse vil jeg her introdusere det jeg betegner som en Nav-diskurs, som rommer måter denne institusjonen artikulerer sitt samfunnsoppdrag på.

Forholdet mellom Nav-diskursen og diskurser fra profesjonen, fra domenet «tolk», er interessant å se nærmere på. I hvor stor grad trekkes det på diskurser fra profesjonen når Nav setter utvikling av tolkens rolle på sin agenda? 


\section{Makt og myndighet}

Solheim og Øverlid påpeker i Samhandling i velferdsyrke (2001, s. 186) at «Ein tekst som er skapt og boren fram av (...) tunge aktørar, har makt». Nav er utvilsomt en slik aktør, som forvalter av velferdsgodet tolk og dessuten som arbeidsgiver for tolkene. Nav er en tung aktør også i forhold til utdanningen, som institusjon, blant annet fordi tolketjenesten ved hjelpemiddelsentralene er utdanningens viktigste praksisarena.

Tolkeutdanningen sorterer ikke under samme departement som Nav, og arbeidsgruppen som har levert rapporten har heller ikke hatt i oppdrag å vurdere denne. Likevel kommer de med forslag som angår tolkeutdanningen og dens innhold:

Arbeidsgruppa ser det også som viktig at tolkeutdanningene utvider tolkens perspektiv på tolkerollen og deres kunnskapsgrunnlag. ${ }^{2}$

Noen diskurser er myndigere enn andre (Syltevik, 2013, side 32) og jeg vil argumentere for at Nav-diskursen er en slik. Syltevik forklarer myndige diskurser som privilegerte diskurser, i det at de konstituerer konteksten for den politiske debatten på et tidspunkt.

Myndige diskurser kan være institusjonalisert og understøttes av autoritetsstrukturer som for eksempel byråkrater, administratorer og eksperter.

Nav-diskursen er institusjonalisert, og autoritetsstrukturen er åpenbar. I rapporten tas det til orde for en enda sterkere tilknytning til denne strukturen. Det refereres til tolketjenestens innplassering i hjelpemiddelsentralene og at arbeidsgruppen «ser det som viktig» at den «forankres i de overordnede utviklingsdimensjonene for NAV Hjelpemidler og tilrettelegging» (Fornying av tolketjenesten, 2011, s. 17).

At formidlingen av velferdsgodet tolk er lagt til et byråkratisk system, skal sikre like rettigheter for alle brukerne og kvalitetssikre tjenesten (Mjøen, 2004). Innen samfunnsvitenskapen diskuteres hvorvidt byråkrati er den mest ideelle måten å fordele goder og hjelp på, i spenningen mellom hjelp og kontroll (Hansen, Lundberg og Syltevik, 2013). Fra døveorganisasjonens side omtales imidlertid den norske modellen for tolkeformidling som «verdens beste», men samtidig ønsker døve en større myndighet i forhold til denne (Gjøen, 2008).

La oss ikke slippe makt og myndige diskurser riktig ennå. Det er mange måter å forstå makt på. Her vil det først og fremst være snakk om definisjonsmakt, og det er som blant andre Fairclough (1995) peker på, gjennom språkbruk at noen ideer vinner fram og får større makt enn andre.

På det feltet som her diskuteres, er det flere institusjoner enn Nav som er bærere av antatt myndige diskurser: tolkeutdanningen - gitt sitt samfunnsoppdrag å utdanne nye tolker, og brukerorganisasjoner - som har rettigheter til tolk. En annen institusjon, som i kraft av sin profesjonsmakt burde være leverandør av en myndig diskurs i spørsmålet om å definere tolken, er nettopp Tolkeforbundet. Men ingen av disse institusjonene høres i den diskursive praksisen som produksjonen av Nav-rapporten utgjør.

Tolkeforbundet fikk rapporten til uttalelse $i$ etterkant og ble invitert til å stille med to representanter til arbeidet med del 2, som omhandler frilansordningen, men altså ikke den delen som går på tolkerollen. Norges Døveforbund fikk som brukerorganisasjon en orientering om deler av rapporten på sitt topplederseminar 2011, også det etter at arbeidet var avsluttet (Herland, 2011).

Dette kan virke som et paradoks, all den tid det forfektes at tolketjenesten skal «forankres $\mathrm{i}$ en levende diskusjon om tjenestens verdigrunnlag og etiske fundament» og videre, at:

2 (Fornying av tolketjenesten, 2011, s. 18.) 
«Bare slik kan visjonen om en tjeneste på brukernes premisser forbli livskraftig» (utheving i originalteksten) (Fornying av tolketjenesten, 2011, s. 19).

Ved ikke å inkludere aktører fra nevnte institusjoner, blir diskurser derfra gjort ikke myndige, slik Syltevik karakteriserer diskurser som er relativt fraværende hos dem som utøver politikk (2013, s. 32).

Produksjonen av rapporten framstår dermed som lukket: et internt Nav-anliggende. Dette kan også ses som en form for maktutøvelse. Riktignok handler det her om tolker i hjelpemiddelsentralene, men hvem er det som ikke kommer inn under de reglene som utformes der? Det kommer også eksplisitt til uttrykk et sted i teksten at de omfatter både ansatte og frilanstolker (punkt 4.5.2).

Gitt det forhold at praktisk talt alle tegnspråktolker i Norge har et arbeidstakerforhold til Nav, enten gjennom ansettelse eller andre avtaler som sikrer lønn for deres arbeid, står også Nav i en særskilt maktposisjon som markedsaktør. Og det kan være vanskelig à se en tydelig grenseoppgang mellom profesjonen som sosial arena for tolkefaglig diskusjon, og Nav som arena for fagutvikling av tolken.

I en kritisk diskursanalyse er det viktig å undersøke hvem som har stått for produksjon av den kommunikative handlingen. La oss derfor se på hvordan arbeidsgruppen som leverte Nav-rapporten var sammensatt før vi går videre. Hvilke sosiale aktører står for produktet som her analyseres?

Rapporten forteller at det var fire tolker med i gruppen, i egenskap av avdelingsledere og/eller tillitsvalgte fra sine respektive tolketjenester, i Nav. Den ene av tolkene er også oppgitt à være prosjektansvarlig sammen med representanter fra Fagenheten og fra Styringsenheten, ved Nav Hjelpemidler og tilrettelegging, som ledet arbeidet.

Selv uten innsyn i hvilke diskusjoner som utspant seg i arbeidsgruppen, men basert på hvordan rapporten er utformet, er det vanskelig å trekke noen annen konklusjon enn at det er Nav-diskursen som preger denne. Det er vanskelig å se spor av en profesjonsdiskurs her, i perspektivene på tolkens rolle. Med den tette koblingen mellom tolk og arbeidsplass, kan det være at Nav-diskursen blir tatt for gitt. Dette er noe Faircolugh (1992) oppfordrer oss til à være ekstra oppmerksomme på. Det som tas for gitt, kan åpne for sosial endring uten a bli problematisert.

\section{Med rett og plikt til å hjelpe}

Det ligger i Navs mandat å skulle hjelpe (Lundberg, 2013). Med Nav som forvalter av velferdsgoder, oppstår det en spenning mellom hjelp og kontroll - også når det gjelder tolketjenestens formidling av tolk som ett av hjelpemidlene døve brukere har krav på. Syltevik (2013, s. 36) viser til at bruker er et mer nøytralt begrep enn klient og at det samtidig signaliserer et aktivt forhold til tjenesten som gis. Brukerbegrepet er innarbeidet også innen profesjonsdiskursen.

Hun viser også til at vi er brukere når vi får tilgang på begrensede velferdsgoder og tolk er ett av disse, selv om målet for tolketjenesten er at «enhver som har behov for tolk, får tolking når man trenger det» (Tolkeutredningen, s. 8). Knapphet på tolkeressurser, gjør at tolketjenesten må fungere som gatekeepers, som vurderer hvem som skal få tolk til hvilke oppdrag. Fra brukerorganisasjonen Norges Døveforbund kreves det bedre tolke-dekning og større innflytelse på organiseringen av tjenesten (Gjøen, 2012). Dette blir imøtekommet i rapportens uttalte intensjon:

«A bedre tjenestetilbudet til tolkebrukerne er fornyingsarbeidets overordnede mål» heter det i beskrivelsen for rapportens bakgrunn (Fornying av tolketjenesten, 2011, side 4). Men hva skal tilbudet gå ut på, og hvilke tjenester er det tolken skal utføre? 
Vi har sett at det ligger i Navs mandat en forpliktelse til å hjelpe brukerne. Og det er denne diskursen jeg finner spor av i måten en fornying av tolkerollen framstilles på. Det kommer tydelig til uttrykk i punkt 4.5.2 Nar kommunikasjonen ikke fungerer, der det slås fast at tolken da «bør kjenne både plikt og rett til å foreslå tiltak som kan bedre kommunikasjonen» (min utheving). Vi merker oss at dette ikke kun skal gjelde for Navansatte tolker, men gjelde «uavhengig av om man er ansatt eller frilans».

Dette kan ses som et eksempel på hvordan ytre krefter forsøker å skape endring i en profesjons juridiksjonsområde (Abbott, 1988) - gjennom å påvirke organisasjonens ansvarsområde. Innbakt i Nav-språket (Lundberg og Syltevik, 2013) ligger her en forståelse av tolkerollen som bærer bud om at også tolken skal ha rett og plikt til å hjelpe. Hvilke tiltak det er snakk om, fra Nav sin side, er ikke mulig å lese ut av rapporten ut over at det ofte kan være «enkle grep». Men det kan også kan være snakk om «større tilrettelegginger og tilpasninger», noe som «kan kreve involvering av andre fagpersoner - ved hjelpemiddelsentralen, i kommunen eller i andre fagmiljøer» (Fornying av tolketjenesten, 2011, s. 17).

Innen tolkeprofesjonen holdes tolkens taushetsplikt fram som en absolutt verdi. Den er nedfelt i de yrkesetiske retningslinjene og står i en særstilling der. Brudd på taushetsplikten er det eneste punktet som kan utløse juridiske sanksjoner. Da blir det fra et tolkefaglig ståsted vanskelig å forstå hvordan tolken skal kunne involvere «andre fagpersoner» uten å komme i konflikt med taushetspliktens strenge krav. Og hva skal de involveres i? La oss gå tilbake til det første punktet i Nav-teksten.

\section{Et utvidet tolkebegrep}

Innledningsvis i teksten forklares «tolkens kjerneoppgaver» (punkt 4.5.1) som «å bistå i kommunikasjonen mellom døve, døvblinde og hørselshemmede på den ene siden og hørende på den andre». Her artikuleres også en hørende part som tolkebruker, noe som kan tyde på at diskurser fra andre diskursordener har vunnet gehør også innenfor Nav. Dette blir enda tydeligere når vi leser videre: «Tolkingen innebærer oversettelse mellom ulike språk og skjer ved hjelp av ulike tolkemetoder og ved hjelp av tilrettelegging». Hvis det med til- rettelegging for eksempel menes à sette opp teknisk utstyr for skrivetolking ${ }^{3}$, vil måten å definere tolking på være i tråd med definisjoner vi finner innen utdanningen, som diskursorden. En definisjon som der brukes, er denne:

Interpreting is a form of Translation in which a first and final rendition in another language is produced on the basis of a one-time presentation of an utterance in a source language (Pöchhacker, sitert i Scholdager, 2008, side 188).

Vi skal imidlertid ikke lete lenge for å finne formuleringer som tyder på at tolken, i Navsystemet, tiltenkes oppgaver utover det som tekster fra utdanning og profesjon beskriver som tolkens ansvar ${ }^{4}$.

Skaaden (2013) framholder at tolkens ansvarsområde defineres av de yrkesetiske retningslinjene. For taletolker gjelder Retningslinjer for god tolkeskikk, utgitt av Kommunalog arbeidsdepartementet (1997) mens tegnspråktolker forholder seg til Tolkeforbundets retningslinjer for etikk og yrkesutøvelse (Tolkeforbundet, 2011).

Der er ingen prinsipielle forskjeller på disse, men de siste tar høyde for at tolken skal formidle visuell og auditiv informasjon ${ }^{5}$, i tillegg til å oversette. Tolkeforbundets etiske

3 Skrivetolking, en form for intralingual tolking, krever teknisk utstyr for formidling av talt norsk til skriftlig norsk via skjerm. Dette kan kreve en tilrettelegging, og inngår i opplæring av tolken.

4 Se for eksempel Wadensjö (1998) om tolkerollen.

5 Visuell informasjon - for døvblinde tolkebrukere, og auditiv for hørselshemmede. 
retningslinjer er utformet og endret gjennom årene av profesjonen selv, og vi ser at deres definisjon av tolkens oppgaver også legges til grunn i offentligheten, som i Helsedirektoratets veileder om kommunikasjon via tolk (Helsedirektoratet, 2011).

Det er gjennom å organisere seg og definere sine oppgaver, at en profesjon oppnår sin makt (Abbott, 1988). Men det kreves anerkjennelse fra samfunnet for at profesjonen skal beholde makten. Jeg vil argumentere for at den myndige Nav-diskursen utfordrer tegnspråktolkens profesjonsmakt. Den utfordrer også døves identitetskonstruksjon som språklig minoritet, selv om vi har sett at språkdiskursen ikke er helt fraværende.

Et syn på døve som funksjonshemmede, og behovet for å minske gapet mellom individets forutsetninger og samfunnets krav (som det heter innen en slik diskurs), trer tydelig fram i et annet Nav-dokument: Tolkeutredningen (2008).

Allerede der varsler Nav at de har tanker om «framtidens tolkerolle», som stiller nye krav til tolken:

Alle tolker må, på ny og på ny, stille seg spørsmålet: Er tolking det riktige for å skape kommunikasjon, gitt akkurat dette behovet og denne situasjonen? Er det behov for noe annet i tillegg til eller i stedet for tolking? Slike overveielser forventes av enhver fagperson under utøvelsen av sitt yrke. Derfor må det forventes av alle tolker at de alltid har et våkent blikk for om det bør settes inn andre tiltak, i tillegg til eller i stedet for tolking (...).(Tolkeutredningen, 2008, s. 56).

Her tar Nav til orde for en type skjønnsutøvelse som ligger utenfor det en tolk forventes å kunne foreta. Skaaden (2013) advarer i sin lærebok i tolking, Den to-partiske tolken, mot à sette tolken i en posisjon der hun/han må utøve skjønn ut over tolkens tradisjonelle oppgave: direkte tolket samhandling, og Skaaden presiserer samme sted at «det er innenfor dette smale, men komplekse domenet tolken utøver skjønn» (side 190).

Sitatet fra Tolkeutredningen gir derimot signal om at Nav ser tolkens rolle mer som et ledd $\mathrm{i}$ deres hjelp til funksjonshemmede. Tiltakene det refereres til, kan både «være innrettet på å endre krav og forutsetninger i brukernes omgivelser, og eventuelt på å endre situasjonen som utløste behovet for tolkingen» (Tolkeutredningen, 2008, side 57). Videre heter det:

I lys av dette er det vesentlig at tolketjenesten forankres i en forståelse av tolkerollen som handler om å fremme menneskers funksjon, og som ser tolking som funksjonsfremmende arbeid og derfor som noe mer enn ren oversettelse.

Med denne formuleringen er vi langt utenfor det smale, men komplekse tolkedomenet for en to-partisk tolk. I Tolkeutredningen trer altså Navs eierforhold til tolken fram ikke bare i sammenheng med deres ansvar for å distribuere tolk som gode, men også i forhold til tolkens rolle. Og endringer i rollen, i forhold til slik vi kjenner den fra profesjonens yrkesetikk, sannsynliggjøres selv om det sies at «i grunntrekkene vil framtidens tolkerolle trolig forbli som den er i dag» (side 57).

En tilnærming til denne endringsdiskursen, kan være å stille spørsmålet: Hva er det Nav forstår som problemet som krever endringer i tolkerollen? Analyser av politiske debatter, der en ser på hvordan problemet implisitt og eksplisitt er forstått, viser at problemforståelsen er en del av politikken (Syltevik, 2013, s. 32).

Om det her ligger en implisitt problemforståelse til grunn, kan det handle om et instrumentelt syn på tolken, som verktøy for å oppnå de overordnede mål som Nav er pålagt av de styrende myndigheter. Eksplisitt problemforståelse forstår jeg som en bekymring for at tolken ikke er i stand til å løse de problemer døve har i kommunikasjon med hørende. Hvis målet er likestilling i arbeidsliv og i samfunnet for øvrig, er det verdier 
som døveorganisasjonen selv kjemper for. Men - er det tolkens ansvar å løse andre problemer enn de som oversettingen kan by på?

\section{...med hvilke konsekvenser?}

Interessepolitiker i NDF, Sissel Gjøen, tegner et bilde av døve som myndiggjorte som resultat av at norsk tegnspråk har fătt en høyere status, at det ikke lenger er stigmatiserende å bruke språket i det offentlige rom. «De fleste døve krever anerkjennelse for sin annerledeshet», skriver hun (Gjøen, 2008). Hun artikulerer ikke døve som hjelpetrengende og viser til at dagens tekniske løsninger, som nettbank, gjør det lettere å takle hverdagen. Gjøen peker her på samfunnsmessige endringer som også har medført at «tolkerollen er endret fra 'hjelper' til profesjonell yrkesutøver» (s. 143).

Dette synes å stå i sterk kontrast til den fortellingen vi finner i Nav-rapporten, om forventninger til hva tolken skal være og ikke være. Det siste er ikke minst viktig for en profesjon å avklare, i og med at det å trekke grenser mot tilstøtende profesjoner, er med på å definere profesjonen (se Abbott, 1988).

Nå er det fullt mulig å forstå tolkeprofesjonen annerledes enn slik dagens yrkesetiske retningslinjer framstiller den. Fra tolkefaglig litteratur kjenner vi til ulike roller tolken kan tillegges (se for eksempel Jareg og Pettersen, 2006). Det kan tenkes at Nav ser for seg tolken som fortaler for den døve, for å bruke et begrep fra Skaaden (2013, s. 177).

Jeg vil argumentere for at det er en helt ny rolleforståelse vi kan lese ut av Navdokumentet, sammenlignet med den rene språktolken, når der vises til behov for innhenting av «samtykke» i de situasjoner hvor «tolkebrukeren motsetter seg andre tiltak enn tolking» (Fornying av tolketjenesten, 2011, s. 18; min utheving).

Tolken skal også skoleres i funksjonsvurdering, går det fram av punkt 4.5.3. Her hevdes det at det vil være en styrke at tolketjenesten er en del av hjelpemiddelsentralene, hvor det gis «tilgang på en fagtradisjon forankret i brukernes premisser der tiltak alltid baseres på konkrete vurderinger av funksjon» (utheving i originaltekst). Og igjen slår funksjonshemmet-diskursen inn når formålet med funksjonsvurderingen er å komme opp med «forslag til tiltak som kan minske gapet mellom individets forutsetninger for og omgivelsenes krav til kommunikasjon» (s. 17).

Det er klart at det ikke er tolking som fagtradisjon det vises til her. Og selv om det andre steder i teksten refereres til at tolking skjer mellom to språk og følgelig mellom to parter i tolkesituasjonen, artikuleres her kun den ene parten som bruker - hvis «forutsetninger for kommunikasjon» vil styre behovet for grad av tiltak.

Også innen taletolking er det en tendens til at det er den ene parten, den minoritetsspråklige, som forstås som den som trenger tolk (Skaaden, 2013). Men derfra og til à pålegge tolken ansvar for å vurdere vedkommende sine forutsetninger for kommunikasjon, er et langt steg.

Det er ikke ukjent at det kan stilles forventninger til tolken, som går på integriteten løs. Innen tolkedomenet oppfordres tolken til å informere om sine yrkesetiske retningslinjer og prinsippene for god tolkeskikk (Skaaden, 2013) for å unngå å komme i en slik situasjon.

I Nav-rapporten vektlegges også etikk, men det er ikke tolkens yrkesetikk det vises til der. Derimot trekkes det på en helsefaglig diskurs i punkt 4.5.4, som tar for seg «Selvbestemmelse, samtykke og hjelpeplikt» (Fornying av tolketjenesten, 2011, s. 18). Der vises det til at pasienter i stor grad har selvbestemmelsesrett foran helsepersonells hjelpeplikt, og «Arbeidsgruppa ser ingen grunn til at dette bør forholde seg annerledes på tolkeområdet» (Fornying av tolketjenesten, 2011, s. 18). 
Dette forstår jeg som at tolkebruker (her: den hørselshemmede) skal ha rett til å avslå «tiltak ut over tolking», som tolken kan komme med - basert på sin «funksjonsvurdering». At det ikke er uproblematisk å innføre en hjelpeplikt for tolken, går fram av rapportens punkt 4.5.6 hvor «Utforming av etikkgrunnlaget for utvidet og samtykkebasert hjelp til brukerne» (s. 18) listes opp som første utfordring i utvikling av tolkens rolle innen Nav.

Her rører vi ved tolkens tillit, profesjonens berettigelse. Som Guldbrandsen (2000) peker på, har ikke den som gir tillit kontroll over de framtidige handlingene til den personen som tilliten rettes mot (s. 79). Yrkesetiske retningslinjer og sanksjonsmuligheter $\mathrm{i}$ forhold til disse, reduserer risiko i relasjonen til profesjonelle yrkesutøvere - som brukerne må gi tillit.

Dersom det blir uklart hvilket mandat tolken har, rokker man samtidig ved den tilliten tolken er avhengig av. Rokkes det ved denne, blir også profesjonen umyndiggjort og den makt profesjonen har, hviler nettopp på en tillit (Froestad og Solvang, 2000) som forutsetter at brukerne vet hva den står for.

\section{Avsluttende diskusjon}

Som nevnt var det ingen brukerrepresentanter med i arbeidsgruppen som leverte Navrapporten, og dermed kom det heller ingen reaksjoner på visjonen om å «gi brukerne hjelp ut over selve tolkingen», fra dem det gjelder.

Som tolkebrukere er døve opptatt av bedre tilgang til tolk og bedre kvalitet på tjenesten (Gjøen, 2008). Samtidig er den politiske delen av døvebevegelsen tydelig på at det er døve selv som skal ha kontroll over sitt eget livsprosjekt. I den forbindelse understreker Gjøen betydningen av tilgang på god tolking. Det dreier seg om ytringsfrihet, slår hun fast. I samme tekst går hun i rette med forestillingen om at det er tolken som er «brobygger» mellom døve og hørende, en utbredt metafor også innen tolkediskursen.

Er det ikke vi døve selv som bygger bro til storsamfunnet gjennom å ha et godt språklig fotfeste i tegnspråk og samtidig et tospråklig og kunnskapsmessig fundament som sikrer jevnbyrdig interaksjon blant hørende? (Gjøen, 2008, s. 145).

Dette sitatet fra Gjøen formidler en helt annen diskurs enn den jeg finner i Nav-rapporten. Det er vanskelig å se for seg en «jevnbyrdig interaksjon» om tolken skal ha den rollen som Nav-diskursen formidler og som utfordrer forståelsen av tolken som nøytral, upartisk (Tolkeforbundet, 2011), eller to-partisk (Skaaden, 2013).

Det er den nøytrale tolken Gjøen setter opp som ideal når hun sier det slik: «Tolken har hatt en god dag på jobben når de andre ikke la merke til at hun er der» (2008, s. 145).

Fra tolkedomenet er det også tatt avstand til tolken som en hjelper for tegnspråktolking (se for eksempel Skaaden, 2013, Kermit 2001). Da kan det synes underlig at endringene Nav vil innføre for tolkerollen, ikke vakte reaksjoner fra profesjonen. Jeg ser to mulig àrsaker til det: den ene er at denne delen av rapporten har fătt lite oppmerksomhet i forhold til alle de endringene som går på tolkens praktiske arbeidsforhold.

En annen mulig forklaring er den jeg allerede har antydet - at forholdet mellom profesjonens medlemmer og Nav som arbeidsgiver kan gjøre at en del ting blir tatt for gitt, noe som kan få store konsekvenser for tilliten til tolken.

Den diskursive praksisen, produksjonen av og konsumpsjon av teksten, har skjedd innenfor rammer av et lite og tett miljø. Etter en kronikk i Døves Tidsskrift, hvor det ble stilt spørsmål ved prosessen og resultatet (Skaten, 2012), satte Tolkeforbundet diskusjonen om Navs forventninger til tolkerollen på dagsorden. Dermed fikk aktører både blant tolkebrukerne og profesjonsutøverne del i det som begynte som en lukket prosess. 


\section{Konklusjon}

Hernes (2002) hevder at «full juridiksjon er målet for en hver profesjon : arbeidsområder som de i kraft av lovgivning har entydig kontroll over» (s. 47). Tegnspråktolkens profesjon kan ikke vise til noen lovgivning som gir profesjonen entydig kontroll over sitt arbeidsområde, men der gis en sertifisering som tolk, gjennom eksamen fra tolkeutdanningen. Dette regulerer markedet, og tolkens yrkesetiske retningslinjer gir tolkebrukerne tillit til hva de kan forvente seg.

Så har vi sett at en profesjon aldri er ferdig definert (Abbott, 1988). Og i denne artikkelen har jeg vist at det finnes flere diskurser, mer eller mindre myndige, som kjemper om a definere tegnspråktolkens rolle. At ytre krefter forsøker å påvirke en profesjon, er imidlertid ikke spesielt og andre vil kunne kjenne seg igjen i beskrivelser av en slik diskursiv kamp. Hvordan Nav-diskursen, som her er diskutert, vil påvirke tolking som sosial praksis, blir et nytt forskningsspørsmål. Ut fra mitt materiale, kan jeg bare konkludere med at Navdiskursen peker ut en helt ny retning for tolken - og at de motstridende diskurser som kjemper om å definere rollen etterlater tolken i en tvetydig posisjon. 


\section{Figur 1: «Tiltak for å utvikle tolkens rolle i hjelpemiddelsentralene» ${ }^{6}$}

\subsection{Tiltak for å utvikle tolkens rolle i hjelpemiddelsentralene}

Arbeidsgruppa ser det som viktig at tolketjenesten, sammen med all annen virksomhet ved hjelpemiddelsentralene, forankres i de overordnede utviklingsdimensjonene for NAV Hjelpemidler og tilrettelegging.

- Styrking av brukermøtet

- Kompetansebygging

- Effektivisering

- Forsvarlig forvaltning

Hva innebærer det at tolketjenesten er en del av hjelpemiddelsentralene? Hva innebærer det for brukerne, for tolketjenesten og for hjelpemiddelsentralene? Arbeidsgruppa vil fremheve seks aspekter i utviklingen av tolkenes og tolketjenestens rolle i hjelpemiddelsentralene:

\subsubsection{Tolkens kjerneoppgaver}

Tolking er i utgangspunktet og i mange sammenhenger å regne som en førstelinjetjeneste. Et særlig kjennetegn ved tjenesten er den meget nære brukerkontakten. Tolkens kjerneoppgave er å bistå i kommunikasjonen mellom døve, døvblinde og hørselshemmede på den ene siden og hørende på den andre. Tolkingen innebærer oversettelse mellom ulike språk og skjer ved hjelp av ulike tolkemetoder og ved hjelp av tilrettelegging.

\subsubsection{Når kommunikasjonen ikke fungerer}

I enkelte tolkesituasjoner er tolken ofte den som ser at kommunikasjonen ikke fungerer. Årsaken kan ligge i selve oversettelsen, men det kan også være at samtalepartene har for få felles referansepunkter til at kommunikasjonen kan flyte godt slik at misforståelser ikke oppstår. Kanskje er det bare tolken som ser vanskene med å legge forholdene til rette for en god kommunikasjon.

Når kommunikasjonen ikke fungerer, bør tolken - uavhengig av om man er ansatt eller frilans - kjenne både plikt og rett til å foreslå tiltak som kan bedre kommunikasjonen. Ofte kan det dreie seg om enkle grep som kan gjennomføres umiddelbart og i situasjonen. Andre ganger må det større tilrettelegginger og tilpasninger til, tiltak som også kan kreve involvering av andre fagpersoner - ved hjelpemiddelsentralen, i kommunen eller i andre fagmiljøer.

\subsubsection{Funksjonsvurdering og kompetanse på andre løsninger}

Som regel vil tolken og tolkebruker komme til enighet om å undersøke og utprøve andre tiltak som kan støtte opp under tolkehjelpen og bedre kommunikasjonen. I stor grad vil dette avhenge av måten tolken tar opp temaet på, og av tolkens faktiske kunnskap om andre tiltak.

For tolken vil det i slike situasjoner være en styrke at tolketjenesten er en del av hjelpemiddelsentralene. Denne tilknytningen gir tilgang til en fagtradisjon forankret $\mathrm{i}$ brukernes premisser der tiltak alltid baseres på konkrete vurderinger av funksjon. I de tilfeller der tolkehjelpen ikke er tilstrekkelig til å skape god kommunikasjon, vil formålet

6 (Fornying av tolketjenesten, 2011, s. 17-18). 
med en funksjonsvurdering være å komme opp med forslag til tiltak som kan minske gapet mellom individets forutsetninger for og omgivelsenes krav til kommunikasjon. En annen styrke ved tilknytningen til hjelpemiddelsentralene er den tilgangen dette gir til et bredt fagmiljø med kompetanse på alternative løsninger.

\subsubsection{Selvbestemmelse, samtykke og hjelpeplikt}

Hva gjør man som tolk i de situasjoner der tolkebrukeren eventuelt motsetter seg andre tiltak enn tolking? Kan man som tolk i det hele tatt foreta seg noe uten tolkebrukers samtykke? Fins det plikter og rettigheter som tolken i slike situasjoner må følge?

I dag fins det ingen retningslinjer på tolkeområdet som regulerer tolkebrukernes rettigheter og tolkenes plikter i de situasjoner tolkebrukeren motsetter seg de ideer og forslag tolken måtte ha utover tolkingen. Men på helseområdet og i helseretten er det gjort en svært grundig behandling av tilsvarende etiske, faglige og juridiske problemstillinger. I ti år har pasientrettighetslovens krav til alle medisinske undersøkelser og behandlings-vedtak vært at det må skje på grunnlag av pasientens samtykke. I helseretten går respekten for individets integritet meget langt og gis langt på vei forrang fremfor hensynet til à redde liv. I stor grad går pasientens selvbestemmelsesrett foran helsepersonellets hjelpeplikt, og Arbeidsgruppa ser ingen grunn til at dette bør forholde seg annerledes på tolkeområdet.

\subsubsection{Taushetsplikt og rett til vern mot spredning av opplysninger}

Tolkebrukeren har rett til vern mot spredning av opplysninger fra tolkesituasjonen. Denne retten til konfidensialitet avspeiles i tolkens taushetsplikt. Retten til konfidensialitet er begrunnet i flere hensyn:

- $\quad$ hensynet til tolkebrukerens personvern

- hensynet til tillitsforholdet mellom tolkebruker og tolk

- hensynet til at tolkebrukeren skal få best mulig tolkehjelp

Tolkebrukers rett til vern mot spredning av opplysninger og tolkens taushetsplikt må ivaretas også hvis andre fagpersoner og fagmiljøer involveres for å gjøre kommunikasjon best mulig. For øvrig gjelder Etiske retningslinjer for statstjenesten også for tolker ansatt i NAV.

\subsubsection{Fire utfordringer}

Som en sammenfatning vil Arbeidsgruppa peke på fire utfordringer i utviklingen av tolkens rolle i hjelpemiddelsentralene:

1. utforming av etikkgrunnlaget for utvidet og samtykkebasert hjelp til brukerne

2. dyktiggjøring av tolker i brukermedvirkning

3. bygging av tolkers kompetanse i funksjonsvurdering

4. stimulering av tverrfaglige arbeidsmåter ved hjelpemiddelsentralene

Arbeidsgruppa vil også peke på at hvis brukerne skal få hjelp utover selve tolkingen, må Tolketjenesten tilføres både kompetanse og ressurser. Og skal andre ansatte ved hjelpemiddelsentralen inngå $i$ et tverrfaglig samarbeid for å løse tolkebrukernes behov, må disse dyktiggjøre seg i tolkefaglige problemstillinger, regelverk m.m. Arbeidsgruppa ser det også som viktig at tolkeutdanningene utvider tolkenes perspektiv på tolkerollen og deres kunnskapsgrunnlag. 


\section{Referanser}

Abbott, A. (1988). The System of Professions : An Essay on the Division of Expert Labor. Chicago: The University of Chichago Press.

Breivik, J-K. (2000). «Sosial konstruksjon av døv identitet». I J. Froestad, P. Solvang \& M. Söder (Red.), Funksjonshemming, politikk og samfunn (s. 137-161).Oslo: Gyldendal akademisk.

Burr, V. (2003). Social Constructionism. London og New York: Routledge.

En samlad tolktjänst : samordning och utveckling av tolktjänst för barndomsdöva, vuxendöva, hörselskadade och personer med dövblindhet. SOU 2011 :83, Stockholm: Fritzes.

Et helhetlig rehabiliteringstilbud til hørselshemmede : Plan for utvikling og organisering av tjentestetilbudet (2002) [Handlingsplan] Oslo: Helsedepartementet.

Fairclough, N. (1992). Discource and Social Change. Cambridge: Polity Press.

Fairclough, N. (1995). Critical Discource Analysis : the critical study of language. London: Longman.

Fornying av tolketjenesten Del 1: Organisering og fagutvikling, tjenester og lønns- og arbeidsvilkår. (2011). NAV Hjelpemidler og tilrettelegging.

Froestad, J. \& P. Solvang, (2000). «Forskning om funksjonshemning; konstruksjon og narrasjon, profesjon og stat». I: J. Froestad, P. Solvang og M. Söder (red.)

Funksjonshemning, politikk og samfunn. Oslo: Gyldendal akademisk (s. 17-32).

Gjøen, S. (2008). «Verdens beste tolkeordning». I: H. Herland (red.), Tegnspråkets fremtid-vart felles ansvar (s. 139-145). Bergen: Norges Døveforbund.

Gjøen, S. (2012). «Tolketjenesten må bli bedre». Døves Tidsskrift. Nr. 6/2012.

Gulbrandsen, T.(2000). «Om tillit». Sosiologi i dag, årgang 30, nr. 3, s. 67-95.

Hansen, H-T., K.G. Lundberg, K.G. \& L.J. Syltevik (2013). «Brukeren i det 21. århundret nye og gamle velferdsdilemmaer». I: H-T. Hansen, K.G. Lundberg \& L.J. Syltevik (red). Nav - med brukeren i sentrum? Oslo: Universitetsforlaget. (s. 174-185).

Haualand, H. (2002). I endringens tegn : Virkelighetsforståelser og argumentasjon $i$ døvebevegelsen. Oslo: Unipub forlag.

Helsedirektoratet. (2011). Veileder om kommunikasjon via tolk for ledere og personell $i$ helse og omsorgstjenestene. Oslo.

Herland, H. (2011). «På brukernes premisser». Døves Tidsskrift. Nr. 7/2011, s. 3.

Hernes, H. (2002). «Perspektiver på profesjoner». I: B. Nylehn \& A.M. Støkken (red.), De profesjonelle (s. 38-51). Oslo: Universitetsforlaget.

Jareg, K. \& Z. Pettersen (2006). Tolk og tolkebruker - to sider av samme sak. Bergen: Fagbokforlaget.

Jørgensen, M.W. \& L. Phillips (1999). Diskursanalyse som teori og metode. Fredriksberg: Roskilde Universitetsforlag.

Kermit, P. (2001). «Utviklingstrekk i tolkeprofesjonens yrkesetikk». Tolkeavisa nr. 2/2001, s. $8-10$.

Lundberg, K.G. (2013). «Individualiserte mål, standardiserte løsninger, lokalt skjønn og brukernes kompetanse». I: H-T. Hansen, K.G. Lundberg \& L.J. Syltevik (Red.) Nav med brukeren i sentrum? Oslo: Universitetsforlaget (s. 91-109). 
Mjøen, O.M: Nasjonal standard for tolketjenesten. Oslo: Rikstrygdeverket, Hjelpemiddelkontoret.

Mål og meining : Ein heilskapleg norsk språkpolitikk (2009). St.meld. nr. 35 (2007-2008). Oslo: Kultur- og kyrkjedepartementet.

Schjoldager, A., H. Gottlieb og I. Klitgård (2008). Understanding translation. Aarhus: Academica.

Skaten, I. (2005). Tolk, døvetolk - eller tegnspråktolk? : En diskursanalytisk undersøkelse av identitetskonstruksjon hos tolkestudenter. Bergen: Sosiologisk institutt, Universitetet i Bergen.

Skaten, I. (2012). «NAV vil utvide tolkerollen, med hvilke konsekvenser?» Døves Tidsskrift, $1 / 2012$, s. $16-17$.

Skaten, I. (2013). «The Power of the Profession, taken for granted?» I: B.van den Bogaerde, L. Hollman \& M. Salami (ed.) Be aware! Power and responsibility in the field of sign language interpreting. Proceedings of the $20^{\text {th }}$ efsli Conference Vienna, Austria, $14^{\text {th }}-16^{\text {th }}$ September 2012. European Forum of Sign Language Interpreters (s.86-95).

Solheim, L.J. \& B. Øverlid (2001). Samhandling i velferdsyrke. Bergen: Fagbokforlaget. Skaaden, H. (2013). Den topartiske tolken : Lærebok i tolking. Oslo: Universitetsforlaget. Syltevik, L.J. (2013). «Brukeren i debatten om Nav-reformen». I: H-T. Hansen, K.G. Lundberg \& L.J. Syltevik (Red.) Nav - med brukeren i sentrum? Oslo: Universitetsforlaget (s. 31-46).

Tolkeforbundet (2011, 10.04.). Tolkeforbundets retningslinjer for etikk og yrkesutøvelse. Hentet fra http://tolkeforbundet.no/main/component/content/article. Lest 25.09.14.

Tolkeutredningen. (2008). [Oslo]: Arbeids- og velferdsdirektoratet.

Torgersen, U. (1972). Profesjonssosiologi. Oslo: Universitetsforlaget.

Wadensjö, C. (1998). Kontakt genom tolk. Stockholm: Dialogos förlag.

Wilensky, H. (1964). «The professionalization of everyone?» American Journal of Sociology, 70, 137-138.

http://dx.doi.org/10.1086/223790 